\title{
An open-access database of grape harvest dates for climate research: data description and quality assessment
}

\author{
V. Daux ${ }^{1,2}$, I. Garcia de Cortazar-Atauri ${ }^{3,4}$, P. Yiou ${ }^{1}$, I. Chuine ${ }^{4}$, E. Garnier ${ }^{5,6}$, E. Le Roy Ladurie ${ }^{7}$, O. Mestre ${ }^{8}$, and \\ J. Tardaguila ${ }^{9}$ \\ ${ }^{1}$ LSCE/IPSL, laboratoire CEA/CNRS/UVSQ, UMR8212, Gif/Yvette, France \\ ${ }^{2}$ Université Versailles Saint Quentin en Yvelines, Versailles, France \\ ${ }^{3}$ INRA-Agroclim, Avignon, France \\ ${ }^{4}$ CEFE, Montpellier, France \\ ${ }^{5}$ CRHQ UMR CNRS Université de Caen, Caen, France \\ ${ }^{6}$ Institut Universitaire de France, Paris, France \\ ${ }^{7}$ Collège de France, Paris, France \\ ${ }^{8}$ Météo-France, Toulouse, France \\ ${ }^{9}$ Universidad de la Rioja, Logroño, Spain
}

Correspondence to: V. Daux (valerie.daux@1sce.ipsl.fr)

Received: 13 July 2011 - Published in Clim. Past Discuss.: 15 November 2011

Revised: 13 July 2012 - Accepted: 24 July 2012 - Published: 3 September 2012

\begin{abstract}
We present an open-access dataset of grape harvest dates (GHD) series that has been compiled from international, French and Spanish literature and from unpublished documentary sources from public organizations and from wine-growers. As of June 2011, this GHD dataset comprises 380 series mainly from France (93\% of the data) as well as series from Switzerland, Italy, Spain and Luxemburg. The series have variable length (from 1 to 479 data, mean length of 45 data) and contain gaps of variable sizes (mean ratio of observations/series length of 0.74 ). The longest and most complete ones are from Burgundy, Switzerland, Southern Rhône valley, Jura and Ile-de-France. The most ancient harvest date of the dataset is in 1354 in Burgundy.

The GHD series were grouped into 27 regions according to their location, to geomorphological and geological criteria, and to past and present grape varieties. The GHD regional composite series (GHD-RCS) were calculated and compared pairwise to assess their reliability assuming that series close to one another are highly correlated. Most of the pairwise correlations are significant $(p$-value $<0.001)$ and strong (mean pairwise correlation coefficient of 0.58). As expected, the correlations tend to be higher when the vineyards are closer. The highest correlation $(R=0.91)$ is ob-
\end{abstract}

tained between the High Loire Valley and the Ile-de-France GHD-RCS.

The strong dependence of the vine cycle on temperature and, therefore, the strong link between the harvest dates and the temperature of the growing season was also used to test the quality of the GHD series. The strongest correlations are obtained between the GHD-RCS and the temperature series of the nearest weather stations. Moreover, the GHDRCS/temperature correlation maps show spatial patterns similar to temperature correlation maps. The stability of the correlations over time is explored. The most striking feature is their generalised deterioration at the late 19th-early 20th century. The possible effects on GHD of the phylloxera crisis, which took place at this time, are discussed.

The median of all the standardized GHD-RCS was calculated. The distribution of the extreme years of this general series is not homogenous. Extremely late years all occur during a two-century long time window from the early 17 th to the early 19 th century, while extremely early years are frequent during the 16th and since the mid-19th century. 


\section{Introduction}

Grapevine (Vitis vinifera L.) harvest dates (GHD hereafter) have been identified as accurate documentary proxies to study past climate evolution in Europe (Brazdil et al., 2005; Jones et al., 2009). The analysis of the dependence of GHD on climate was first undertaken by Dufour (1870) who constructed a stacked series of GHD in Switzerland extending back to the 15th century. Then Angot (1883) built a comprehensive dataset of French and Swiss GHD series and performed analyses of the variability of GHD through space and time. The earliest date of the series he compiled belongs to the 14th century. Several decades later Garnier (1955), Le Roy Ladurie (1967) and Legrand (1978) highlighted the potential of GHD as climate proxies, and revived the scientific community's interest in GHD data. Le Roy Ladurie (1967) collected more than a hundred GHD series from southern France, with a few ones also going back to the 14th century. The GHD series from Burgundy compiled by Angot (1883) have been completed, extended and stacked to produce a sixcentury long, almost continuous, GHD series (Chuine et al., 2004), and used to produce several climate reconstructions (Chuine et al., 2004; Etien et al., 2008; Guiot et al., 2005, 2010; Le Roy Ladurie, 1967, 2005; Le Roy Ladurie et al., 2006; Luterbacher et al., 2004; Menzel, 2005; Pfister, 1992; Schleip et al., 2008; Souriau and Yiou, 2001; Xoplaki et al., 2005).

\subsection{Grapevine and temperature}

The grapevine is a perennial long-lived plant adapted to warm and dry environments. Currently, it develops in areas where the mean temperature of the growing season (AprilOctober in Northern Hemisphere) ranges between $13^{\circ} \mathrm{C}$ and $20^{\circ} \mathrm{C}$, which corresponds approximately to the $33-50^{\circ}$ latitude belts (Jones et al., 2005). However, because of these thermal needs, the area where grape is planted has changed through time. For instance, vineyards planted in southern England from the 10th to the 13th century, which disappeared from the British landscape during the cooling of the Little Ice Age (Gladstones, 1992; Jones et al., 2005), were reintroduced there after World War II, and have expanded since then.

The development of the grapevine is mainly driven by temperature (Jones, 2003). The key developmental stages are budbreak, flowering and veraison (time when grapes change their colour) (Jones, 2003). The budbreak requires firstly a chilling period to break winter dormancy followed by a prolonged exposure to higher temperatures which promote cell elongation (Lavee and May, 1997). In northern countries, the grapevine typically breaks bud in April-May, flowers occur in June, and the veraison at the end of July or during August. The ripening phase initiates at the veraison and finishes when grapes have reached a certain level of maturity. Currently, in France, the grape harvest is most often scheduled between
10 September and 10 October (Van Leeuwen et al., 2008), i.e. 30 to 40 days after the veraison (Chuine et al., 2004).

The delay between the veraison and the grape harvest is quite constant in a vineyard. For example, the standard deviation of such a delay is of 0.74 days for 26 series in the Alsace vineyard (Chuine et al., 2004). Furthermore, correlations between flowering and veraison dates with GHD are very high in each vineyard (i.e. in the Alsace vineyard, $r=0.90$, $p<0.0001$ and $r=0.92, p<0.0001$, respectively; Chuine et al., 2004).

\subsection{Scheduling of the grape harvest}

Prior to the French revolution, in most areas, wine owners were not free to harvest at their convenience. They had to wait for a public order to harvest ("ban des vendanges") (de la Poix de Fremenville, 1758; Pocquet de Livonnière, 1733; Rageau and De Laurière, 1704; Salvaing de Boissière, 1664). The harvest date was a considered seigniorial or municipal decision (Garnier et al., 2011). In practice, the scheduling of grape harvest was incumbent on several wine-growers and/or qualified persons who visited the vineyards to assess the maturity level of the grapes (de la Poix de Fremenville, 1758). After the revolution, vine-growers were theoretically free to begin the harvest when they wanted to (law of $4 \mathrm{Au}-$ gust 1789). In practice, most parishes maintained a compulsory minimum date for grape harvest in order to preserve law and order (Le Roy Ladurie and Daux, 2008). After 1791, the date was set by the mayor, on vine growers' advice (Law of 6 October 1791). When several varieties were grown in a same area, the official date corresponded to the earliest and/or to the most important variety. The law of 9 July 1889 entitled the municipalities to keep or give up the "ban des vendanges" practice, which led to its disappearance in almost all France. At the same time, different new diseases, such as the downy mildew, the powdery mildew and especially the phylloxera, appeared and ravaged the vineyards.

In France, since 1979 (decree 79-868), the harvest date has been determined by the Prefect's service on a proposal of the National Institute of Origin and Quality (INAO), after the notice of the agency defined for each vineyard (i.e. Interprofessional Committee for Champagne Wine, Interprofessional Board of Burgundy Wines, Interprofessional Council for Bordeaux Wines, etc), taking into account the planting and the status of vineyards. In some cases, different official dates can be proposed, according to types of wine and varieties (Garcia de Cortazar-Atauri et al., 2010). In neighbouring countries (Germany, Italy, Spain and Switzerland), the system is similar to the French one, with some national particularities.

\subsection{Grape harvest dates and temperature}

Due to the strong control of temperature on grape ripening, GHD are linked to the growing season temperature (hereafter 
GST: mean or maximum temperature averaged generally over April-August). Several authors have thus evidenced statistically significant correlations between GST and GHD series. Menzel (2005) showed that the variation of the GHD of a mean European series was $10.2 \pm 0.9$ days for $1{ }^{\circ} \mathrm{C}$ variation of the GST. Meier et al. (2007), Daux et al. (2007) and G. Jones (personal communication, 2010) also calculated rates around 10 days $/ 1^{\circ}$ for varieties grown respectively in Switzerland, France and western USA. As GHD are linked to temperature, GHD-series have been used to reconstruct the variations of temperature through time. Two methodologies are currently in use: linear regression models (LRmodels) (Etien et al., 2008, 2009; Meier et al., 2007; Menzel, 2005) and process-based phenological models (PBP-models) (Chuine et al., 2004). Garcia de Cortazar et al. (2010) compared temperature reconstructions performed with the two methods and concluded that both were accurate. However, they have also emphasised that, contrary to the linear regression one, the process-based method does not rely on a local calibration of the temperature/GHD relation but can be applied to any region or time period provided that the model has been parametrized for the grapevine variety considered.

Considering the strong link they have with temperature, GHD are valuable proxies for this meteorological parameter. They can be used for reconstructing temperature variations through time using linear regression or process-based phenological models. The present paper describes a GHD database that we will make available on Internet. This database includes datasets mentioned above as well as many unpublished series. It gathers 380 GHD series of variable length from all the French vineyards and from some Spanish, Swiss, Italian and German ones. Over the description of the structure of the database, we propose a grouping of series into 27 composite series according to geological, geomorphological, historical and viticultural criteria in order to produce series representative of a region. The quality of these regional series is assessed by correlations of the GHD-series two-bytwo and with instrumental temperature series.

\section{Material and methods}

\subsection{Grape harvest dates collection}

The database is composed of 380 individual GHD series. 93 percent corresponds to French vineyards, and the remaining seven percent from neighbouring countries (Germany, Switzerland, Spain and Italy) (Fig. 1a). The various origins of the series can be categorised as follows:

- Series published in easily accessible recent literature (e.g. GHD from Besançon published in Garnier et al. (2011));

- Series published in French books (e.g. a hundred series from southern France in Le Roy Ladurie (1967));
- Series published in French-language journals in volumes that exist only as paper versions (e.g. 60 series from different French vineyards in Angot (1883) and Legrand (1978));

- Unpublished series collected from public organizations and services (Towns Archives, Chambers of Agriculture, Direction Départementale de l'Agriculture et de la Forêt, MétéoFrance, etc);

- Unpublished series collected from private winegrowers.

The information and date copying was carried out with care by the authors of the present publication and the series were controlled for typing errors. Most of the original documents were photographed or digitised and can be consulted.

The series published by Angot (1883), which make up an important part of the database, were collected in 1881 by the Central Meteorological Office ("Bureau Météorologique Central") who enjoined local committees ("Commissions départementales") to take an inventory of GHD. As numerous civil servants have been involved in the inventory process, the quality of the data reporting may have been very variable. For instance, the Dijon GHD series was recompiled recently from municipal archives and about $25 \%$ of the dates in the new compilation (Labbé et al., 2011) were different from the ones published in Angot (1883). Some original documents (Chobaut's collection in the multimedia library of Avignon) used in Le Roy Ladurie (1967) were also revisited; some gaps were filled in the Northern Rhône valley and Southern Rhône valley series and three new series of the Burgundy region were found: Chaignay, Marsanay-la-Côte, Marsannais-le-Bois which are respectively 18, 9 and 17-yr long. We also obtained information about changes through time in varieties grown in the Southern and Northern Rhône valley.

\subsection{Regional classification}

The 380 GHD series were grouped into 27 regions (Table 1; Fig. 1b) according to several criteria. The first one is based on the geographical location of the series and the relation it can have with the other ones around. We observed that most of the series of the database come from areas which have produced wine for a long time. Based on Guyot (1868a, $b$, c) who describes grape varieties and production practices adopted in each French department, we evaluated which series were similar enough to be classified in the same region (see below). Using the Protected Designation of Origin database of French communes (URL: www.inao.gouv.fr), we also identified which current vineyard series are related to each region. When available, other documents were also consulted to find supplementary information about varieties (Odart, 1845; Rendu, 1857) or about vineyards (Beaumont, 1899; Chaptal et al., 1801; Clémençot, 1897; Duval, 1900; 

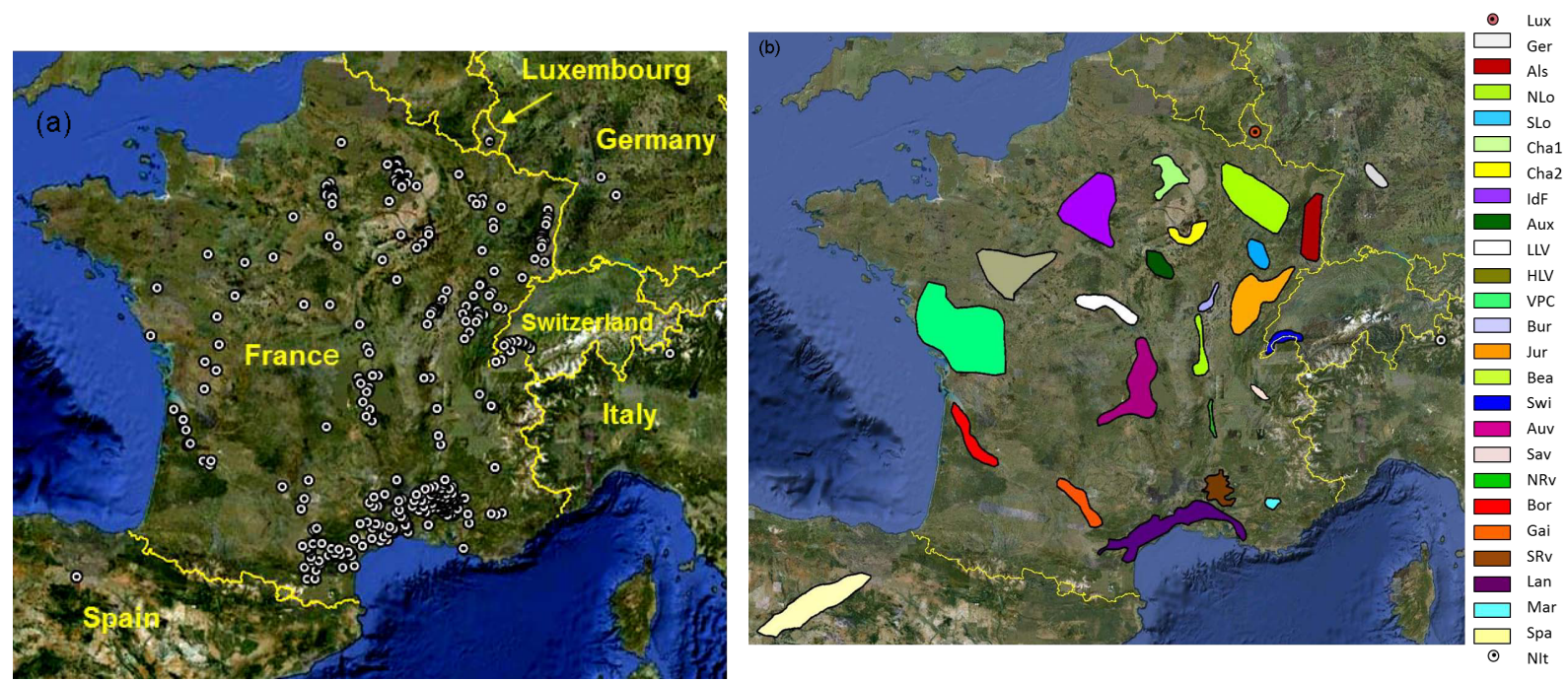

Fig. 1. (a) Location of GHD sites and (b) of the regions defined in Table 1. "Various south east" field is not reported. It corresponds to the series in south-eastern France which cannot be classified in Languedoc, in Maritime Alps or in Southern Rhône valley.

Galet, 2004, 2006; Godinot, 1718; Holdsworth, 1842; LouisPerrier, 1886; Saporta, 1894).

Geomorphological and/or geological variations, which may induce different micro and meso-climatic conditions, inside a vineyard or between two nearby vineyards, can affect the grapevine growth and development (Tardaguila et al., 2011). To improve the accuracy of the classification, we also took into account these variations. Thus, for instance, Burgundy series were separated from "Jura" ones because (1) the two vineyards are separated by a plain, (2) the Burgundy vineyard has a very specific position on the eastern side of the Beaune hill, while the Jura vineyard grows on hills at various altitudes and expositions. Auxerre-Avalon and BeaujolaisMaçonnais vineyards currently belong to the Burgundy vineyard, but the distance, the varieties and the geological differences between the areas have also allowed their separation into different series. A similar situation is observed with the series of Champagne-Epernay and Reims (Champagne 1 hereafter) and Champagne-Côtes des Bar (Champagne 2). These two regions belong to the Champagne vineyard, but they have different substratums (Epernay and Reims are mostly chalky while Côtes des Bar are mostly marl), and are separated by a plain more than $70 \mathrm{~km}$ wide, which may induce differences in local climates. In south-eastern France, the wine-producing area has also been divided into several regions: the area most subjected to the Mediterranean influence was labelled Languedoc region, the more continental one, north of the Alpilles Mountains (mainly Vaucluse and eastern Gard departments), was labelled Southern Rhône valley region and series which cannot be unequivocally related to a vineyard, were gathered together in a various south east category.

\subsection{Database structure}

The main information concerning each GHD series is presented in Table S1 in the Supplement. For each series, the following is provided:

- its name (in many cases the name of the closest town or village),

- the time-period covered,

- the source of the data (with the reference of the document if it is available),

- the current name of the vineyard,

- coordinates (latitude, longitude and altitude),

- the number of observations,

- some additional information when possible (name of the variety, uncertainty of the sources...).

The original GHD series grouped by region are available from the phenological database developed in the GDRproject "Phenologic Information System for Management and Study of Climate Change" (http://www.gdr2968.cnrs. fr/spip.php?rubrique29/) and from the World Data Center for Paleoclimatology (http://www.ncdc.noaa.gov/paleo/ paleo.html).

Following the nomenclature adopted by the pioneers (Angot, 1883), dates are expressed as the number of days after the 31 August (e.g. 1 September is 1, 1 October is 31, 29 August is -2 , etc.). Missing values may correspond to a lack of grape harvest (which may or may not be connected to weather) or to sketchy sources. The dates before $1583 \mathrm{AD}$ were corrected for calendar changes from Julian to Gregorian 
Table 1. Description of the regional composite series of grape harvest dates. Abbr.: abbreviation; Nr.: Number of series included in the composite series. *: series in which quality was analysed more thoroughly.

\begin{tabular}{|c|c|c|c|c|c|c|c|c|c|}
\hline Name & Abbr. & Nr. & Start & End & Length & Gaps & Reference Series & Mean Lat. & Mean Long. \\
\hline Alsace & Als* & 16 & 1700 & 2005 & 306 & 44 & Ribeauvillé; Riquewihr & 48.17 & 7.28 \\
\hline Auvergne & Auv & 15 & 1799 & 1879 & 80 & 1 & Chadeleuf & 45.58 & 3.17 \\
\hline Auxerre-Avalon & Aux & 2 & 1751 & 1879 & 129 & 1 & - & 47.78 & 3.57 \\
\hline Beaujolais and Maconnais & Bea & 4 & 1892 & 1976 & 85 & 12 & Beaujolais & 46.24 & 4.58 \\
\hline Bordeaux & Bor* & 14 & 1449 & 2006 & 558 & 231 & Pichon-Longueville & 45.18 & -0.75 \\
\hline Burgundy & Bur* & 20 & 1354 & 2006 & 652 & 39 & Dijon & 47.32 & 5.04 \\
\hline Champagne 1 & Cha1 & 28 & 1806 & 2006 & 201 & 17 & C1; C2; Sézanne; Aÿ 1 & 49.04 & 3.97 \\
\hline Champagne 2 & Cha2 & 6 & 1799 & 1879 & 81 & 0 & Les Riceys & 47.98 & 4.28 \\
\hline Gaillac- South-West & Gai & 5 & 1483 & 1789 & 307 & 234 & - & 43.9 & 1.9 \\
\hline Germany & Ger & 2 & 1611 & 1830 & 220 & 22 & - & 48.77 & 9.17 \\
\hline High Loire Valley & HLV & 3 & 1600 & 1879 & 280 & 170 & - & 47.07 & 2 \\
\hline Ile de France & $\mathrm{IdF}^{*}$ & 16 & 1478 & 1977 & 500 & 81 & Argenteuil & 48.93 & 2.23 \\
\hline Jura & Jur* & 16 & 1449 & 1976 & 528 & 86 & Salins & 46.93 & 5.88 \\
\hline Languedoc & Lan & 36 & 1524 & 2007 & 484 & 150 & Montpellier & 43.6 & 3.87 \\
\hline Low Loire Valley & LLV* $^{*}$ & 6 & 1801 & 2006 & 206 & 3 & Chinon & 47.15 & 0.22 \\
\hline Luxembourg & Lux & 1 & 1840 & 1949 & 110 & 3 & Grand Duché & 49.67 & 6.13 \\
\hline Maritime alps & Mar & 3 & 1500 & 1796 & 297 & 74 & - & 43.5 & 6 \\
\hline Northern Italy & NIt & 1 & 1623 & 1884 & 262 & 99 & Tirano & 46.22 & 10.17 \\
\hline Northern Lorraine & NLo & 8 & 1752 & 1884 & 133 & 6 & Toul & 48.68 & 5.88 \\
\hline Northern Rhône valley & NRv & 3 & 1537 & 2006 & 470 & 342 & - & 45.48 & 4.83 \\
\hline Savoie & Sav & 3 & 1713 & 1879 & 167 & 44 & - & 45.6 & 6 \\
\hline Spain & Spa & 4 & 1499 & 2007 & 509 & 161 & - & 42.34 & -3.3 \\
\hline Southern Lorraine & SLo & 3 & 1760 & 1879 & 120 & 11 & Châtillon-sur-Saône & 47.98 & 5.88 \\
\hline Southern Rhône valley & $\mathrm{SRv}^{*}$ & 51 & 1433 & 2006 & 574 & 123 & $\begin{array}{l}\text { Pernes-les-Fontaines; } \\
\text { Couvent des Pernes }\end{array}$ & 43.98 & 5.05 \\
\hline Switzerland (Leman Lake) & Swi* & 15 & 1480 & 2007 & 528 & 38 & Lausanne & 46.57 & 6.52 \\
\hline various south east & VSE & 33 & 1543 & 1933 & 391 & 274 & - & 43.74 & 3.47 \\
\hline Vendée - Poitou Charente & VPC & 6 & 1600 & 1877 & 278 & 172 & Saint-Hilaire-de-Talmont & 46.45 & -1.5 \\
\hline Mean & & 12 & 1621 & 1934 & 313 & 90 & & & \\
\hline
\end{tabular}

calendar (Gregory XIII papal bull "Inter gravissimas..." of 1582). To do so, GHD were added by 10 days for the 16 th century, 9 days for the 15 th century and 8 days for the 14 th century.

\subsection{Reference series}

For each region a reference series was chosen. Selection criteria were its length (the longest one is generally chosen) and the quality of the correlation with the other series of the region. When regional datasets presented many incomplete series, more than one reference series was defined (i.e. Southern Rhône valley, Alsace) (Table 1). Following Chuine et al. (2004), the various series of a region were then adjusted by calculation of an adjustment factor as the difference between the mean value of the candidate series and the mean value of the reference one over their common period of record. Then, for each region, a mean composite series (hereafter grape harvest dates regional composite series, GHD-RCS; Tables S1 and S2 in the Supplement; Fig. 2) was calculated as the median of the individual adjusted series of the region. Only GHD series of early varieties were taken into consideration. Some series were excluded from the cal- culation of the composite series of their region because they come from vineyards in special locations (for instance, in higher elevation than the other datasets of the region), they contain too few data, they do not correspond to early varieties or because they are poorly correlated to the other series of the same area, which could introduce some noise in the GHD-RCS (Garcia de Cortazar-Atauri et al., 2010). The discarded series are identified in Table S1 in the Supplement. The availability of GHD decreases back in time. Thus, there are 25 GHD-RCS series in the19th century, but only 7, which are fraught with gaps, before 1499 .

\subsection{Reliability of the sources and statistical methods}

In order to assess the quality of the database and its potential for past climate reconstructions, preliminary analyses of the pairwise GHD-RCS correlations were conducted. Pearson's (linear) correlation coefficients (PCC) were calculated over the entire series and over 15-yr running windows.

The strong dependence of the vine cycle on temperature, and therefore the strong link between GHD and the temperature of the growing season (i.e. Chuine et al., 2004; Daux, 2010; Etien et al., 2009; Meier et al., 2007) provides a mean 


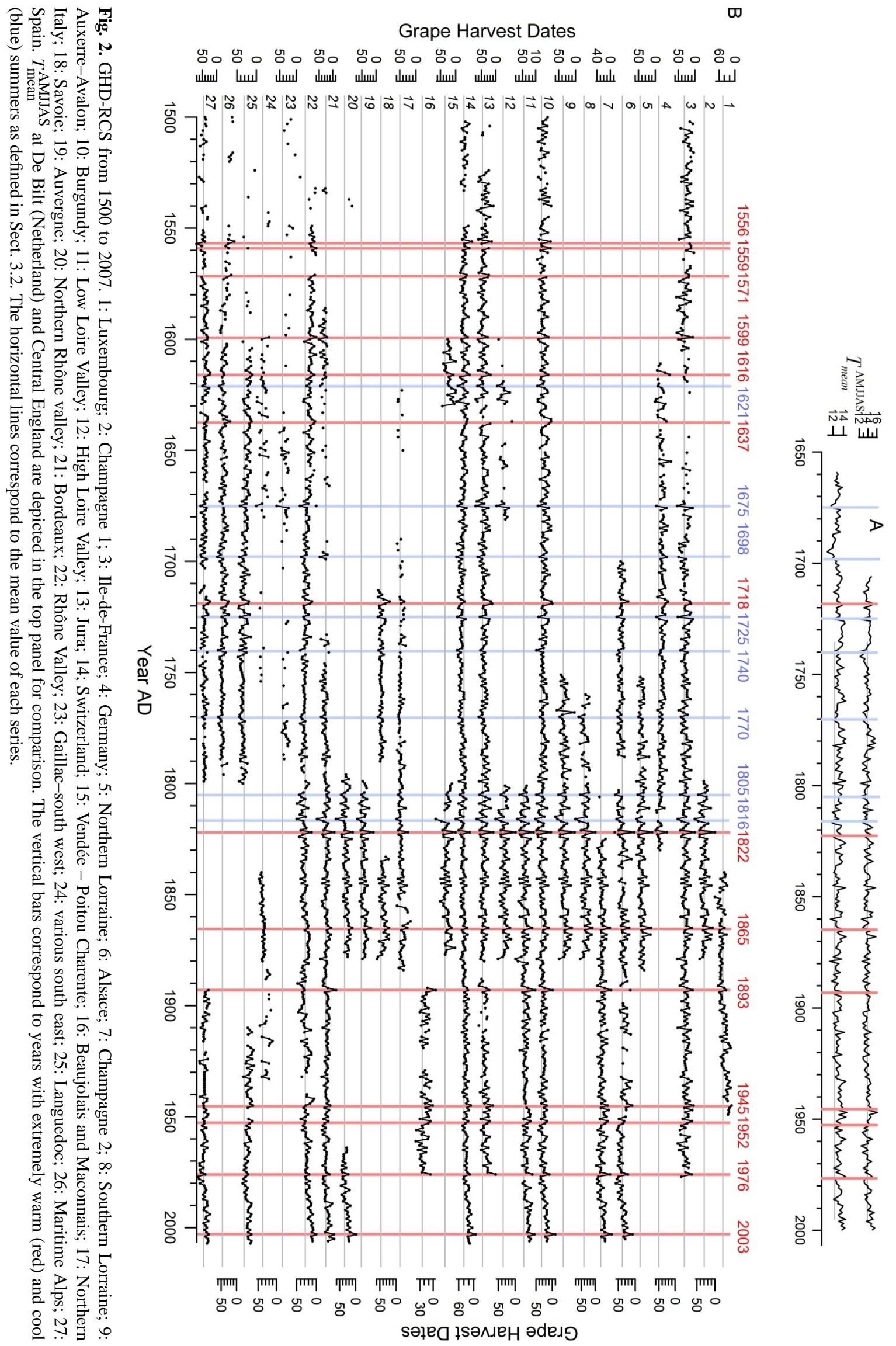


for testing the quality of the GHD dataset. Even if the analysis of the relation between GHD and temperature is more efficiently conducted with a process-based model, it can be achieved by simple correlation analyses (Garcia de CortazarAtauri et al., 2010). We have therefore calculated the correlation coefficients between GHD-RCS and growing season temperature (monthly maximum temperature averaged over April to September: $T_{\max }^{\mathrm{AMJJAS}}$ ) series recorded at 85 stations of the Météo-France meteorological network, at Milan (Italy) (Maugeri et al., 2002a, b), at Karlsruhe and Stuttgart (Germany), at Geneva (Switzerland), at Navacerrada and Salamanca (Spain), and at Luxembourg (Klein Tank et al., 2002) (Table S4 in the Supplement). The start of the instrumental temperature series ranges from 1865 to 1936 . The correlation coefficients between the GHD-RCS and temperature records from Central England and from De Bilt (Netherlands) were also calculated. The CE temperature record starts in 1659 (Manley, 1974), and was updated by (Parker and Horton, 2005). The De Bilt record starts in 1706 (Van Engelen and Geurts, 1983-1992) (van Engelen and Nellestijn, 1996) and was updated by the EC EMULATE project (http: //www.cru.uea.ac.uk/projects/emulate/, Moberg et al., 2006).

\section{Results and discussion}

For some twenty years, various studies, have introduced a note of caution to the use of GHD as climate proxies. Guerreau (1995) considered GHD to be more social than temperature-dependent phenological data. Pfister (1984, 1999) was less categorical but also pointed out the influence of anthropogenic factors on GHD. More recently, Rutishauser et al. (2007) and Meier et al. (2007) came back over this issue and questioned the effect of the context on the stability of the GHD-temperature relation through time.

Garcia de Cortazar-Atauri et al. (2010) and Garnier et al. (2011) have fully discussed this matter. They have identified the major possible causes of flaws in GHD-based temperature reconstructions: uncertainties in the model used to relate temperature to GHD, change of grape varieties and of type of wine through time and unfavourable socio-political contexts. For the first possible flaw, they have shown that PBP-models, which do not rely on the calibration of GHD to local temperature, are robust and yield accurate temperature reconstructions (model efficiency $>0.64$ ). LR-models can produce results very close to those obtained with PBPmodels if quality instrumental temperature data are available for the calibration and if, of course, GHD series overlap with instrumental series.

Garcia de Cortazar-Atauri et al. (2010) reconstructed temperature variations using GHD from Burgundy with a PBPmodel parameterized for various early and late varieties. They showed that the reconstructed temperature series are similar if the input data correspond to varieties from the same group of precocity and more sizable if they correspond to va- rieties of different groups (early/late). In this last case, the difference between the modelled temperatures increases with temperature and can reach about $1{ }^{\circ} \mathrm{C}$. These results suggest that variety changes through time can induce bias in temperature reconstructions. As noted by Garcia de CortazarAtauri et al. (2010), the information about grape varieties may not be available in archives and this source of uncertainty may not be fully handled. It is worth noting, however, that as stated by de Herrera (1818), the varieties planted in a given vineyard must correspond to the same group of precocity if one wants to preserve a certain vine quality. Therefore, the effect of variety changes through time on GHD may be limited.

According to the literature devoted to the vine (see Garcia de Cortazar-Atauri et al., 2012, for references), the definition of the grape maturity has not changed through time and the same quality evaluation criteria have been adopted for centuries. However, the maturity sought at harvest, and therefore GHD, may vary according to the style of wine produced. For instance, in Alsace, where sparkling and sweet wines are produced from the same varieties (Riesling, Pinot gris), GHD are scheduled on average one month later for the sweet wine production than for the sparkling wine one. This example is extreme as most vineyards do not yield wines as different as sparkling and sweet ones. However, when compiling GHD series, caution should be taken not to associate GHD corresponding to different final products.

Using a PBP-model, Garcia de Cortazar-Atauri et al. (2010) have calculated the possible effect on GHD of changes of grape varieties and of wine types by running the model with varying inputs. They have evaluated in this way a maximum uncertainty on GHD of 8 days (which results in about $0.8^{\circ} \mathrm{C}$ maximum possible error in the reconstruction).

While "the labour of the vintage ideally takes place when the fruit is at the most complete state of ripeness"1, the harvest may be purposely delayed or brought forward because of the socio-political context. Garnier et al. (2011) have illustrated this aspect by showing that the scheduling of GHD at Besançon (north-eastern France) has been influenced in one out of ten years by military threat or plague epidemics during the period spanning from the 16th to the 19th century. Estimating an average error on GHD connected to socio-political events is a priori impossible because the distribution of these events does not follow an identifiable probability law. Ideally, to disentangle manmade from climate related effects on GHD, the series should be contextualised. This kind of investigation is not always possible and an alternative to identify the dubious data can be to compare the different series of a given region with each other (see Sect. 2.4) and then the different GHD-RCS with each other (see Sect. 3.1).

\footnotetext{
${ }^{1}$ in: Coxe and Cooper: The Emporium of arts and sciences, Philadelphia: J. Delaplaine, Vol. 2, p. 11, 1812
} 


\subsection{Two-by-two correlations in the GHD-RCS dataset}

The quality of 8 out of the 27 GHD-RCS of this study (Southern Rhône valley, Burgundy, Jura, Switzerland, Alsace, Ilede-France, Low Loire valley and Bordeaux) were analysed thoroughly (investigations on varieties, viticultural practices, type and quality of wine produced over time) in order to use them for past climate reconstructions. The method and the data can be found in Garcia de Cortazar-Atauri et al. (2010) and Yiou et al. (2012). The other GHD-RCS of the database were not analysed in such detail. In this section, we present some investigations based on the pairwise GHD-RCS relations and on the relations between GHD-RCS and temperature series to assess the quality of the grape harvest data.

The results of the pairwise correlations of the GHD-RCS are presented in Fig. 3, Tables 2 and S3 in the Supplement. As GHD-RCS have variable lengths and contain gaps of variable size, the number of data used to calculate the correlation coefficients vary from one to another pairwise correlation. Thus, the correlation coefficients are not comparable to one another. However, taking into account the level of significance ( $p$-value) of the correlations some general comments can be made.

Significant ( $p$-value $<0.001$ ) and strong correlations exist between most GHD-RCS. As expected, the correlations tend to be higher when the vineyards are closer (see some examples in Fig. 3). The highest correlation $(R=0.91)$ are obtained between the High Loire Valley and the Ile-de-France GHD-RCS (which have almost three hundred years in common). GHD-RCS from Italy and Germany show significant correlations with most of the French series. Some correlations show very low values: the lowest are those involving GHD-RCS from Spain, Languedoc, Southern Rhône valley, Luxemburg and various south east.

The stability of the correlations through time was tested by calculating 15 -yr running Pearson correlation coefficients (PCC) between the longest GHD-RCS (i.e. Burgundy, Switzerland, Southern Rhône valley, Jura and Ile-de-France). The correlations with Champagne 2 and Bordeaux GHDRCS (which are shorter) are also discussed hereafter because these series cover well (with very few missing dates) the transition between the 19th and the 20th century which is a critical period regarding the possible effects of the phylloxera outbreak on GHD. The results (Fig. 4) can be summarized as follows:

- Pairwise correlations between all series and the Burgundy GHD-RCS are high $(\mathrm{PCC}>0.7)$ almost all over the 500-yr time period but deteriorate in the 1570-1580 and 1690-1700 intervals. With the Southern Rhône valley GHD-RCS, the PCC correlation curve plunges by the end of the 19th century and recovers from 1950 onwards. The other PCC curves decrease at the turn of the 20th century, with a minimum around 1920, and then increase (back to $\approx 0.7-0.8$ values) from ca. 1940 onwards.

- Pairwise correlations between all series and Ile-deFrance GHD-RCS also decrease in the 1570-1580 and 1690-1700 intervals. The correlation with Southern Rhone valley GHD-RCS falls as soon as 1840; those with the other GHD-RCS show the same patterns as with the Burgundian one.

- Pairwise correlations between all series and the Switzerland GHD-RCS are all high most of the time, but weaken during the 16th and the 18th centuries (around 1750) and at the junction between the 19th and the 20th centuries, earlier with Southern Rhône valley GHDRCS than with the other series. They show a negative peak in the 1990-1995 time window.

- Pairwise correlations between all series and the Southern Rhône valley GHD-RCS are rather stable from the 16th century to 1850 apart for a drop around 1750 . They deteriorate from 1850 onwards and are restored by the second half of the 20th century (maybe earlier but there is a gap in the Southern Rhône valley series between 1920 and 1950).

- Correlations between all series and the Jura GHD-RCS yield no pattern common to all the correlations apart from a drop of the PCC during the 1960-1970 interval. As there are many missing data between 1870 and 1920 in the Jura GHD-RCS no tendency can be drawn for this period.

From these correlations we can conclude that the data from the 16th centuries may not be very reliable as the pairwise correlations are systematically low. At the end of the 17th century, both Burgundy and Ile-de-France show decreased correlations with the other series and with one another. This cannot reflect a common climate effect (which would have not affected the other vineyards) as a common cause would have very likely produced similar responses and therefore a high correlation between Burgundy and Ile-de-France signals. Thus, we have to consider that some data in the Burgundy and Ile-de-France series may be faulty in the 16901700 interval: the harvest may not have been conducted at the time of grape maturity (for unknown reasons) or transcription errors may have occurred. Similarly, some data may be bad in the Southern Rhône valley and Switzerland GHD-RCS around 1750. The main deterioration of the pairwise correlations takes place during an approximately 50yr long window at the junction between the 19th and 20th centuries. This interval is also characterized by many missing dates in the series. The correlation involving the GHDRCS from the Southern Rhône valley weaken at earlier dates. The deterioration of the correlations coincides with the phylloxera outbreak which affected southern France as early as 1863 (precisely in the Southern Rhône valley) and spread all 


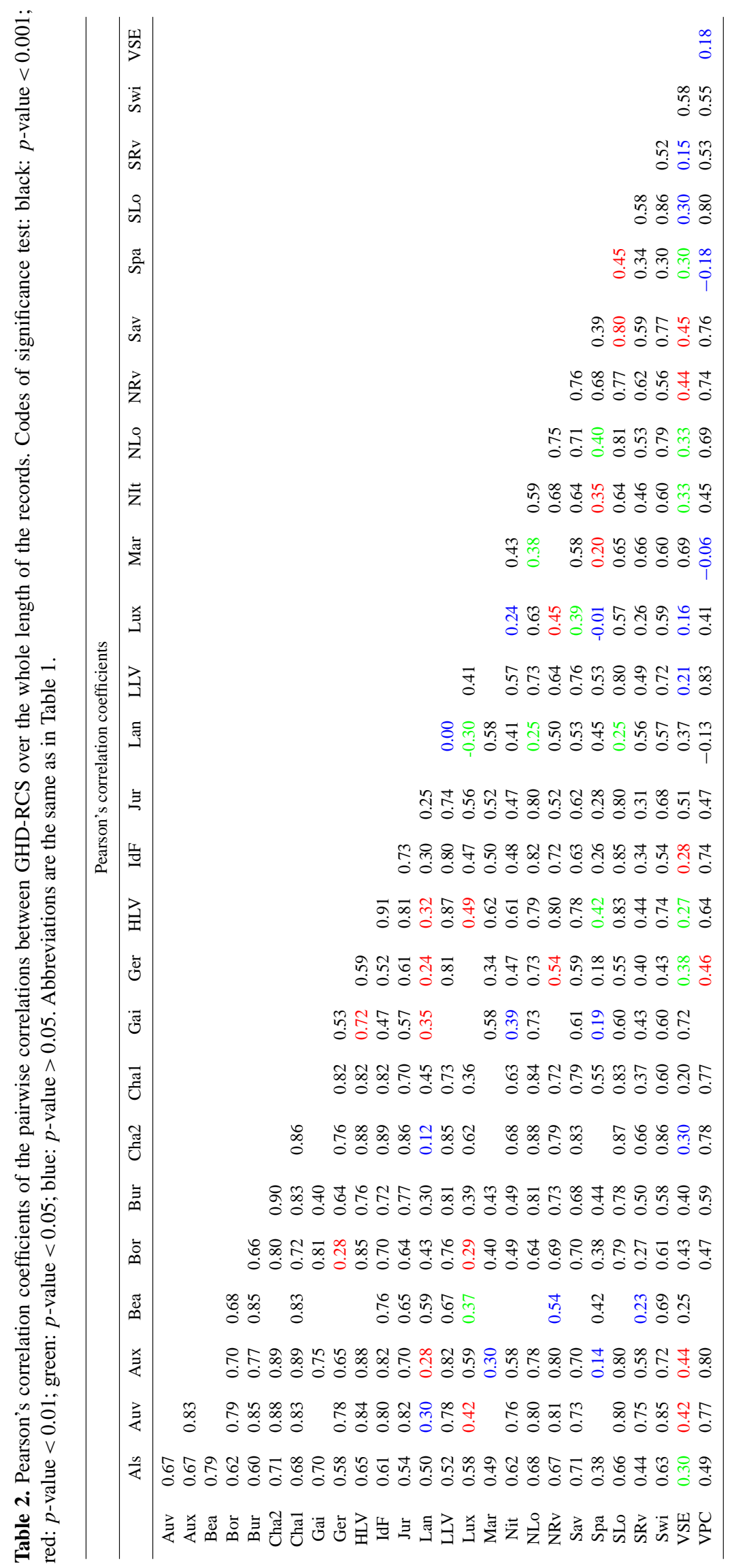



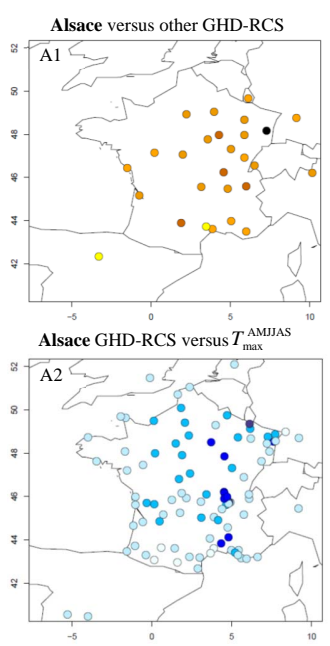

Colmar $T_{\max }^{\text {AMJAS }}$ versus other stations

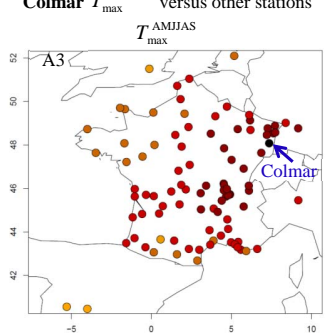

Burgundy versus other GHD-RCS

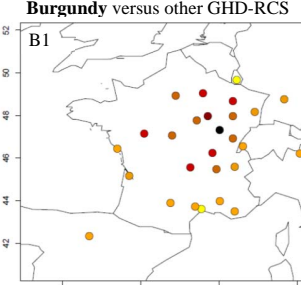

Burgundy GHD-RCS versus $T_{\max }^{\mathrm{AMJAS}}$

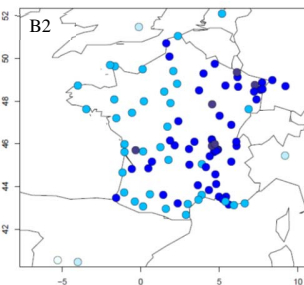

Dijon $T_{\max }^{\text {AMJAS }}$ versus other stations $T_{\max }^{\text {AMJJAS }}$

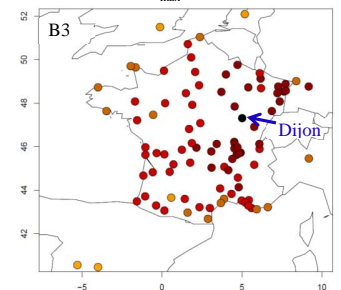

Languedoc versus other GHD-RCS

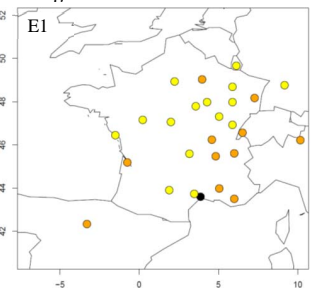

Languedoc GHD-RCS versus $T_{\max }^{\text {AMJis }}$
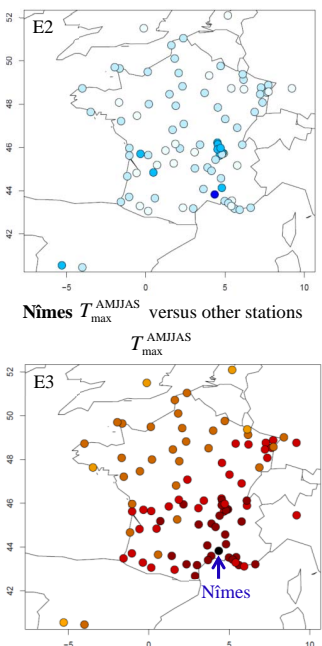

Bordeaux versus other GHD-RCS

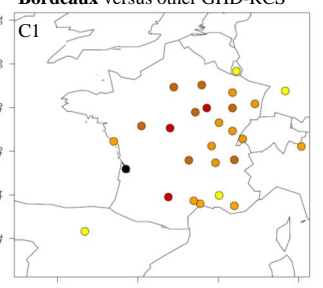

Bordeaux GHD-RCS versus $T_{\max }^{\text {AMJAS }}$

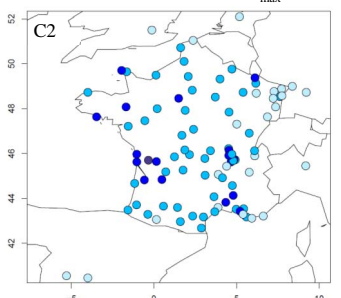

Bordeaux $T_{\max }^{\text {AMJAS }} \stackrel{0}{\stackrel{5}{10}}{ }^{10}$ $T_{\max }^{\text {AMJAS }}$

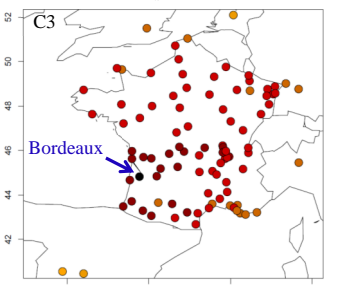

Low Loire Valley versus other GHD-RCS

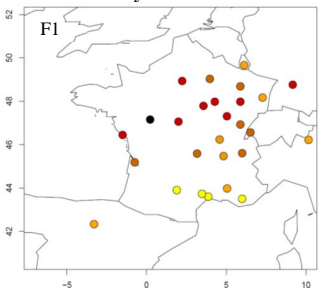

Low Loire V. GHD-RCS versus $T_{\max }^{\text {AMIJAS }}$

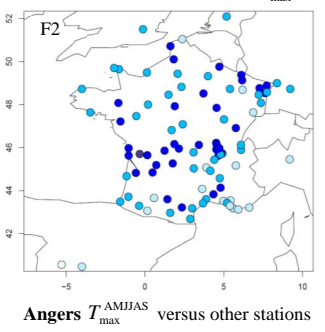
$T_{\max }^{\text {AMJAS }}$

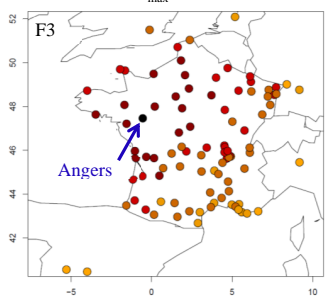

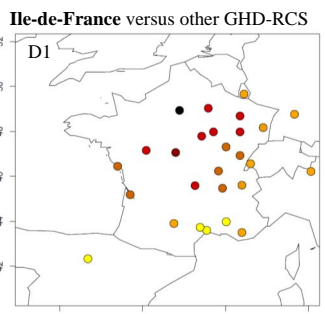

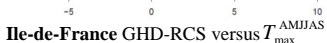

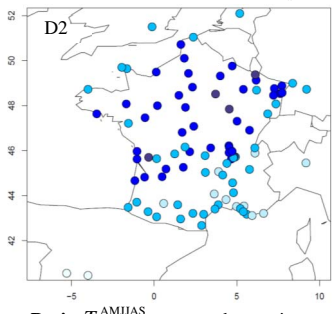

Paris $T_{\max }{ }^{-5}{ }^{\text {AMJAS }}{ }^{0}$ versus other stations $T_{\max }^{\text {AMJJAS }}$

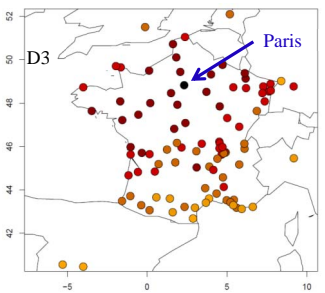

Fig. 3. Comparison of correlation maps. Top panels (1): two-by-two GHD-RCS correlations, intermediate panels (2): GHD-RCS versus $T_{\max }^{\mathrm{AMJJAS}}$ correlations, bottom panels (3): pairwise $T_{\max }^{\mathrm{AMJAS}}$ correlations. Each point is centered on the location of the temperature series. Color code for top and bottom panels: value of the correlation coefficients: $r=1$ : black; $1>r \geq 0.9$ : dark-red; 0.9, $>r \geq 0.8$ : red; 0.8, $>r \geq$ 0.7: dark orange; $0.7,>r \geq 0.6$ : orange; $0.6,>r \geq 0.4$ : light orange; $0.4,>r \geq 0$ : yellow. Color code for middle panel: $-1 \leq r \leq-0.9$ : black; $-0.9<r \leq-0.8$; dark blue; $-0.8<r \leq-0.7$; blue: $-0.7<r \leq-0.6$ : sky blue; $-0.6<r \leq-0.4$ : pale blue; $-0.4<r \leq 0$ : bluish white. 

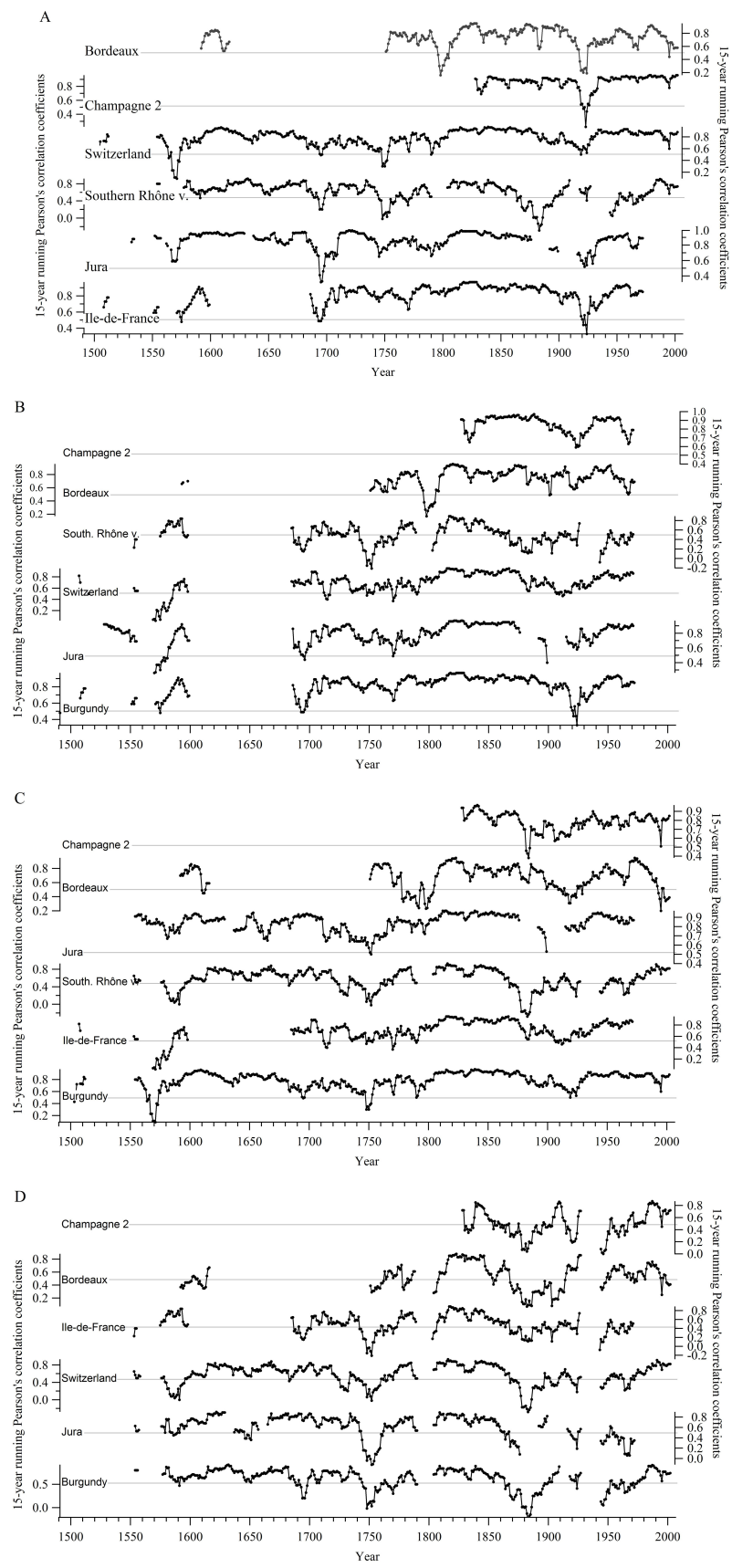

Fig. 4. Variation of the 15-yr running Pearson's correlation coefficients of GHD-RCS pairwise correlations. The name of the GHDRCS correlated with Burgundy GHD-RCS (A), Ile-de-France (B), Switzerland (C) and Southern Rhône valley (D) is reported in each panel. The horizontal lines correspond to the significance level of the PCC (at $p=0.05$ ).

over France (and even Europe) onwards. This parasitic attack devastated French vineyards mainly between 1863 and 1900. Production decreased significantly between 1879 and 1900 (Branas, 1974) and hybrid and high production varieties were selected. With the high demand for wine in France, replanting was hasty but the wine production remained disorganized for years (Spahni, 1988), at least until the 1907 laws of regulation (29 June and 15 July laws, and 3 September decree). New viticultural techniques, in particular the use of American rootstocks upon which the European varieties are cultivated, also affected the production. Rootstocks influence scions, particularly with regard to water uptake, the ability of the grafted combination to increase or decrease uptake and translocation of nutrients and vigor (Coombe and Dry, 1988; Steigler and Howell, 1991; McCarty et al., 1997; Walker et al., 2000; Keller, 2001). However, there is no evidence in the literature that rootstocks affect the phenology of the plant, which depends on the grafted variety (Calo et al., 1979; Eger and Grasselli, 1993) and most of the varieties used after the crisis as scions were identical to those planted before it (Galet, 2004; Odart, 1845; Rendu, 1857). Thus, if the GHD-RCS in the "phylloxera" interval appear less reliable, the deterioration of the quality of the series is not due to phenological changes induced by the adjustment of the viticultural practices but it may be due to the disruption of certain vineyards and to a huge decrease of the number of available data.

\subsection{Correlations between GHD-RCS and the temperature of the growing season $\left(T_{\max }^{\mathrm{AMJAS}}\right)$ over the instrumental time period}

We computed the linear (Pearson) correlation coefficients between the reconstructed (GDH-RCS) and instrumental temperatures $\left(T_{\max }^{\mathrm{AMJAS}}\right)$ for comparison purposes and to check the general consistence of the reconstructions (Table S4 in the Supplement). GHD-RCS which do not have many or even any years in common with temperature series are excluded de facto. Therefore, the correlations with $\mathrm{Au}-$ vergne, Auxerre-Avalon, Champagne1, Gaillac-South-West, Germany, High Loire Valley, Maritime Alps, Northern Italy, Northern Lorraine, Southern Lorraine, Savoie, and VendéePoitou-Charentes could not be investigated.

The correlations between GHD-RCS and $T_{\max }^{\mathrm{AMJJAS}}$ are negative (the hotter the summer, the earlier the grape harvest). Most are significant ( $p$-value $<0.001$ ). As expected, the strongest correlations are obtained between the GHDRCS and the weather series of the nearest stations. The best correlations are those which bring into play: Burgundy, Ilede-France, Low Loire Valley, Northern Rhône valley, Champagne 2 and Switzerland (mean $R \leq-0.67$ ). The poorest are those with: various south east, Luxembourg, Southern Rhône valley and Languedoc (mean $R \geq-0.44$ ). Alsace, Beaujolais and Mâconnais, Bordeaux, Jura and Spain series obtain intermediate scores $(-0.67<$ mean $R \leq-0.58)$. The PCC of 


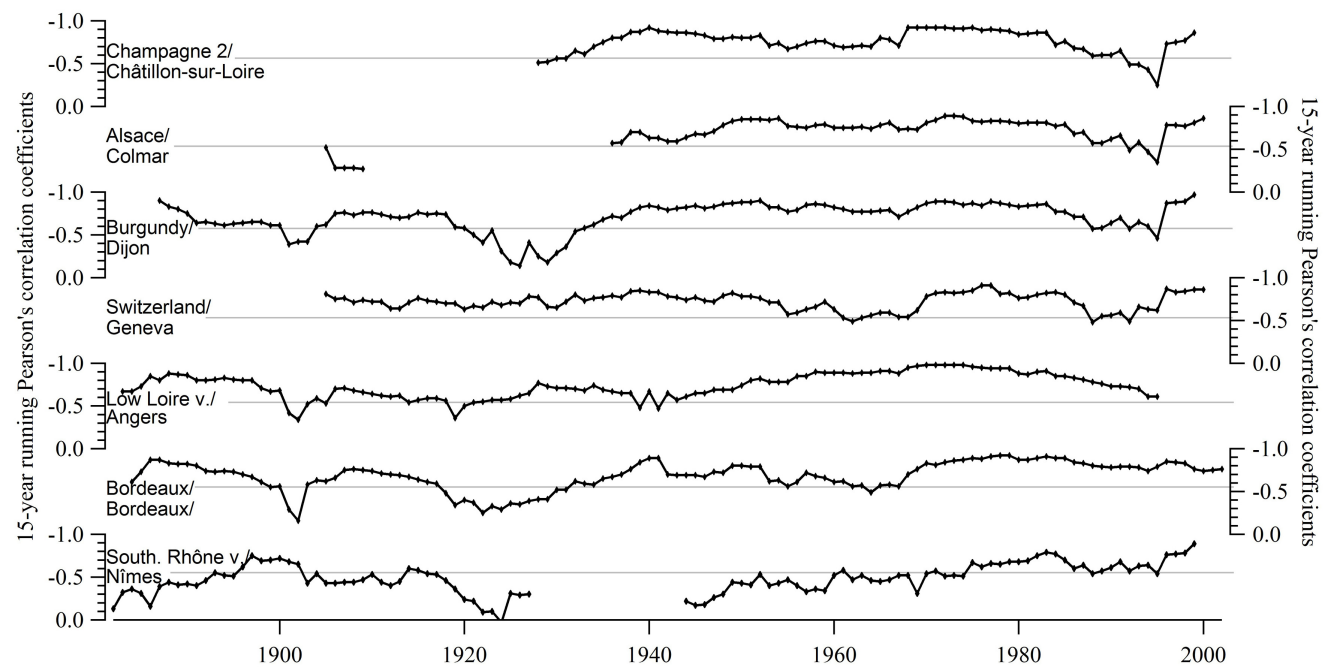

Fig. 5. Variation of the 15-yr running Pearson's correlation coefficients of GHD-RCS- $T_{\max }^{\mathrm{AMJAS}}$ correlations, from top to bottom: Champagne 2 versus Châtillon-sur-Seine, Alsace versus Colmar, Burgundy versus Dijon, Switzerland versus Geneva, Low Loire Valley versus Angers, Bordeaux versus Bordeaux city and Southern Rhône valley versus Nîmes. The horizontal lines correspond to the significance level of the PCC (at $p=0.05$ ).

GHD-RCS with the long $T_{\max }^{\mathrm{AMJAS}}$ series of Central England and De Bilt (Netherland) also reflect the geographical distribution of the sites, with the strongest correlations obtained with the north-western GHD-RCS (the five lowest PCC, all close to -0.7, were obtained for Vendée - Poitou - Charente, Low Loire Valley, High Loire Valley, Champagne 1 and Ilede-France).

The quality of GHD-RCS (on the instrumental time period) can be evaluated by comparing the GHD-RCS/ $T_{\max }^{\text {AMJAS }}$ correlations to the correlations between the $T_{\max }^{\mathrm{AMJAS}}$ of a meteorological station close to the vineyard and the $T_{\max }^{\text {AMJAS }}$ of other meteorological stations (Table S5 in the Supplement; Fig. 3). Though the correlations involving GHD-RCS are lower than those involving only temperature series, the general spatial patterns present similarities. For instance, the distribution of the PCC for

- the Burgundy GHD-RCS versus $T_{\max }^{\mathrm{AMJ} A S}$ series show a north-east-south-west gradient which mimics the distribution of the correlation coefficient between Dijon $T_{\max }^{\mathrm{AMJAS}}$ and the other meteorological stations temperature.

- The Ile-de-France GHD-RCS and $T_{\max }^{\mathrm{AMJAS}}$ series display a north-south distribution similar to the temperature correlation with the Paris meteorological station.

The stability of the temperature - GHD-RCS correlations through time was tested by calculating 15-yr running PCC between GHD-RCS and the $T_{\max }^{\mathrm{AMJAS}}$ series of the closest weather station. These tests could be performed only for GHD-RCS, which contain data in the instrumental time (i.e. Alsace, Champagne 2, Burgundy, Low Loire Valley, Switzerland, Bordeaux, Southern Rhône valley; Fig. 5). Several GHD-RCS (Champagne 2, Alsace, Burgundy, and Switzerland) show weaker correlations, very likely revealing lower reliability of the data, in the 1990s. The decrease of these PCC in the 1990-1995 window echoes the decline of some GHD-RCS pairwise correlations (between the GHDRCS from Swiss, Burgundy, and Southern Rhône valley) described in Sect. 3.1. The correlations with temperature series involving Burgundy, Bordeaux, Southern Rhône valley and Low Loire Valley decrease around 1900 and in the 1918-1930 time window. This result, consistent with those of GHD-RCS pairwise correlations, may reflect combined and detrimental effects of the phylloxera outbreak (and maybe other pests) and of the First World War on vineyards management and grape harvest scheduling.

\subsection{Extreme years and mean levels}

To identify extreme years, we first transformed GHD-RCS in $\mathrm{Z}$-scores series as follows:

$z-$ score $_{i}=\left(\mathrm{GHD}_{i}-\overline{\mathrm{GHD}}\right) / \sigma$

where $\mathrm{GHD}_{i}$ is a date in a GHD-RCS, $\overline{\mathrm{GHD}}$ the mean date of this series and $\sigma$ its standard deviation. We then calculated a "general" $\mathrm{z}$-score series as the median of the $\mathrm{z}$-scores of the GHD-RCS (Fig. 6). Finally, extreme years (i.e. years with an extremely late/early grape harvest, corresponding to an extremely cool/hot growing season), were defined as years with values greater/lower than the average value of the general $z$-score series plus/minus $1.65 \times$ the standard deviation 

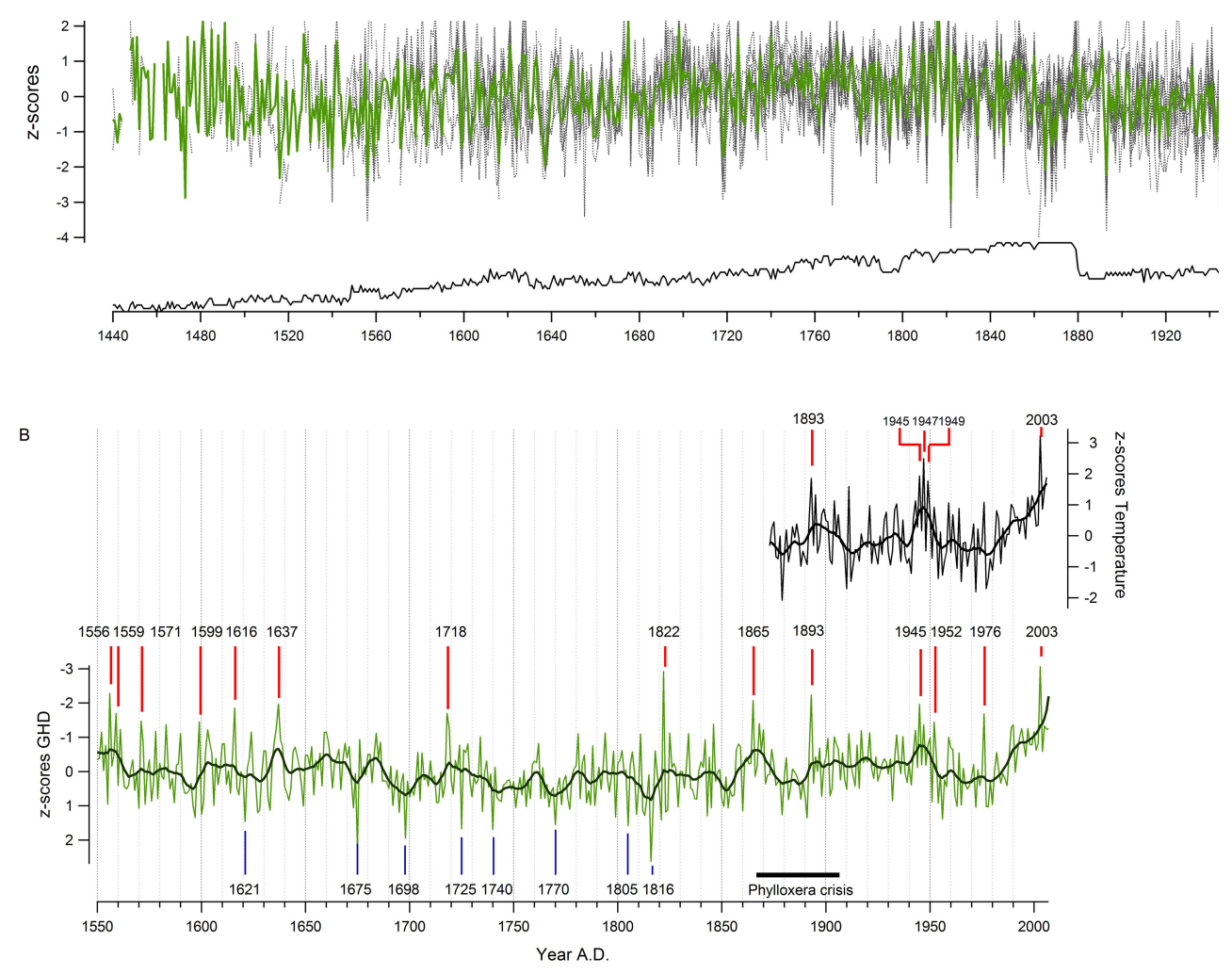

Fig. 6. (A) $z$-scores of the GHD-RCS (grey lines). The median of the z-scores is in green. The number of GHD-RCS available for the calculation of the $z$-score is reported. (B) Top panel: medians of the z-scores of the $T_{\max }^{\text {AMJAS }}$ of the meteorological stations (network depicted in Fig. 3). The red and blue vertical lines correspond respectively to the years of early and late harvests. Bottom panel: medians of the $z$-scores of the GHD-RCS. The red vertical lines correspond to the five highest values. The 11-yr running means are reported as bold lines in each panel.

(which allows the extraction of $10 \%$ of the data). We arbitrarily excluded years for which the number of available GHD-RCS was lower than 5. This led us to discard the years before 1550 .

According to this procedure, the years with extremely hot growing season (April-September) are, by increasing order of GHD earliness: 1952, 1599, 1571, 1976, 1559, 1718, 1616, 1945, 1637, 1865, 1893, 1556, 1822 and 2003. Those with extremely cool growing season are, by decreasing order of GHD earliness: 1621, 1770, 1805, 1725, 1740, 1698, 1675 and 1816. Most of the extremely early/late years correspond to high/low values of the average $T_{\text {mean }}$ at De Bilt and in Central England ( $T_{\text {mean }}$ rather than $T_{\max }$ was chosen here for the comparison with our data because the $T_{\text {mean }}$ records are longer). The exceptions are 1698, which is not cold while the grape harvests are late, and 1945 and 1952 which are not particularly hot while the harvest are early.

Calculation of $z$-scores was also performed with the instrumental $T_{\max }^{\mathrm{AMJAS}}$ series. The medians of the $z$-scores of the temperature series and of the GHD-RCS series present many similarities (Fig. 6b). In particular, they show the same plateau discontinuity in the 1950-1980 interval and the same steep increase since ca. 1980. The 5 hottest years in the instrumental record (which extends only to 2006) are 1896, 1945, 1947, 1979 and 2003. All these years are above the average or extreme according to the GHD record.

The general agreement between the general z-score of the GHD-RCS and the instrumental temperature records confirms the usefulness of GHD as climate proxies.

The distribution of early and late years is not homogenous in the series: extremely late harvest occurred from 1621 to 1816 , while the extremely early ones, except 1718 , occurred before 1637 or after 1822 . Extremely late years all occur during the Little Ice Age, while extremely early years are also frequent at the beginning of the Little Ice Age. The periods of late harvests at the end of the 17th century and in the early 19th century are consistent with the Late Maunder (1675$1715)$ and Dalton minimum (1800-1820). The tendency towards earlier and earlier GHD since 1970 is in agreement with the 20th century warming trend. 


\section{Conclusions}

The presented database includes 16921 grape harvest dates from 380 series, classified in 27 regions. It is freely available for download for scientific or teaching purposes. It will be updated, corrected and expanded as original series or revisions of already included series will become available.

The quality of 8 out of the 27 GHD of this study were analysed thoroughly (investigations on varieties, viticultural practices, type and quality of wine produced over time) in order to use them for past climate reconstructions. The other GHD-RCS of the database were not analysed in such detail. In this paper, we have restricted ourselves to a very general quality assessment of the GHD-RCS by performing pairwise correlations, by comparing them to Météo-France and ECA temperature series (Klein Tank et al., 2002) and by testing the stability through time of these GHD-RCS pairwise correlations and of GHD-RCS - temperature correlations. We strongly recommend a contextualization of the series before interpreting them in terms of climate change

We have accomplished an initial step towards the development of a European dataset which would be very valuable for the analysis of temperature change, weather regimes or atmospheric circulation patterns over the last centuries. The potential of the database is demonstrated in a companion paper which presents a GHD-based reconstruction of the atmospheric circulation over Europe during the Little Ice Age (Yiou et al., 2012).

\section{Supplementary material related to this article is available online at: http://www.clim-past.net/8/1403/ 2012/cp-8-1403-2012-supplement.zip.}

Acknowledgements. This work was funded by grants from the ANR-OPHELIE. We are very grateful to D. Wheeler and to two anonymous reviewers who greatly helped to improve the manuscript. We are indebted to: A. Hourseau for the data from Bouilly, Laroque for the data from Clamart, Rémy BoyerChammard for the new series from Lavérune, T. Labbé for the updated series from Dijon, L. V. Elias for the Rioja data, G. Démarée (Institut Royal Météorologique, Belgium) for providing all the information for the Luxembourg vineyard, S. Lemny for his assistance in collecting data at the "Bibliothèque Nationale de France", W. Trambouze (Chambre d'Agriculture 34) for the data from Herault, O. Jacquet for the data from Mazan, M. Blanc for the data from Visan, F. Boutin for the data from Asperes, C. Riou and O. Roustang (Inter-Rhône) for the data from Rhône Valley, L. Panigai (CIVC) for the data from Champagne, H. Dubois for the Burgundian data and to the Tourist Information Office of Vevey for the "vignoble de Vaux" ones.

Edited by: D. Wheeler

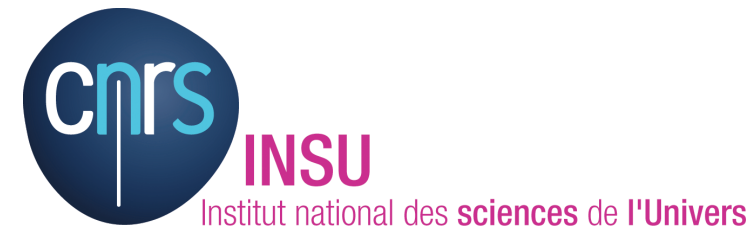

The publication of this article is financed by CNRS-INSU.

\section{References}

Angot, A.: Etude sur les vendanges en France, Annales du Bureau Central Météorologique de France, 29-120, 1883.

Beaumont, J.: La reconstitution du vignoble bourbonnais Moulins, 107 pp., 1899.

Branas, J.: Viticulture, Déhan, Montpellier (France), 1974.

Brazdil, R., Pfister, C., Wanner, H., von Storch, H., and Luterbacher, J.: Historical climatology in Europe - The state of the art, Climatic Change, 70, 363-430, 2005.

Calo, A., Costacurta, A., Liuni, C. S., Spada, S., and Ondradu G.: The phenology of grapevines in Sardinia. Influence of different training forms, varieties and rootstocks, Riv. Viticolt. Enol., 32, $35-41,1979$.

Chaptal, J.-A., Rozier, J.-B. F., and Parmentier, A. A.: Traité théorique et pratique sur la culture de la vigne, avec l'art de faire le vin, les eaux-de-vie, esprit de vin, vinaigres simples et composés, Paris, 2 pp., 1801.

Chuine, I., Yiou, P., Viovy, N., Seguin, B., Daux, V., and Le Roy Ladurie, E.: Grape ripening as a past climate indicator, Nature, 432, 289-290, 2004.

Clémençot, H.: Reconstitution du vignoble dans le canton de Gy et dans la Haute-Saône : Notions générales sur la reconstitution des vignobles, Gray, 56 pp., 1897.

Coombe, B. G. and Dry, P. R.: Viticulture volume 1. Resources in Australia, Adelaide: Australian Industrial Publishers, 1988

Daux, V.: La reconstruction climatique à partir des dates de vendanges, Rev. Bib. Nat. France, 36, 27-34, 2010.

Daux, V., Yiou, P., Le Roy Ladurie, E., Mestre, O., Chevet, J. M., Seguin, B., Chuine., I., Garnier, E., and Viovy , N.: Temperature and Grape Harvest Dates in France, in: "Global warming, which impacts on the vineyards", edited by: Fontaine, P., 10 pp., Dijon, France, 2007.

de Herrera, G. A.: Agricultura General corregida segun el testo original de la primera edicion publicada en 1513 por el mismo autor y adicionada por la real Sociedad Económica Matritense, Imprenta Real, Madrid, 1818.

de la Poix de Fremenville, E.: Dictionnaire ou traité de la police générale des villes, bourgs, paroisses et seigneuries de la campagne, Paris, 588 pp., 1758.

Dufour, M. L.: Notes sur le problème de la variation du climat, Bull. Soc. Vaudoise de Sciences Naturelles, X, 359-556, 1870.

Duval, L.: La vigne dans le département de l'Orne et particulièrement dans le Perche au Moyen Age : Lecture faite à Rémalard, à la séance annuelle de la société historique et archéologique de l'Orne, Alençon, 20 pp., 1900.

Eger, E. and Grasselli, A.: Phenology, grape production and quality of Sangiovese and Trebbiano toscano own-rooted and grafted on five rootstocks, Agricoltura Ricerca, 150, 59-76, 1993. 
Etien, N., Daux, V., Masson-Delmotte, V., Stievenard, M., Bernard, V., Durost, S., Guillemin, M. T., Mestre, O., and Pierre, M.: A bi-proxy reconstruction of Fontainebleau (France) growing season temperature from A.D. 1596 to 2000, Clim. Past, 4, 91-106, doi:10.5194/cp-4-91-2008, 2008.

Etien, N., Daux, V., Guillemin, M. T., Masson-Delmotte, V., Stievenard, M., Breda, N., Boettger, T., Haupt, M., Mestre, O., and Perraud, P. P.: Summer maximum temperature in northern France over the past century: instrumental data versus multiple proxies (tree-ring isotopes, grape harvest dates and forest fires), Climatic Change, 94, 429-456, 2009.

Galet, P. (Ed.): Les vignobles de France. Vol. 1: Méditerranée, Rhône-Alpes, Bourgogne, Franche-Comté, Alsace-Lorraine, Cépages et vignobles de France, Paris, Londres, New York, 1285 pp., 2004.

Galet, P. (Ed.): Les vignobles de France. Vol. 2: ChampagneArdenne, Nord-Picardie, Ile-de-France, Nord-Ouest, Centre, Centre-Ouest, Aquitaine ou Sud-Ouest, Centre-Sud, Cépages et vignobles de France, Paris, Londres, New York, 1275 pp., 2006.

Garcia de Cortazar-Atauri, I., Daux, V., Garnier, E., Yiou, P., Viovy, N., Seguin, B., Boursiquot, J. M., Parker, A., Van Leeuwen, C., and Chuine, I.: An assessment of error sources when using grape harvest date for past climate reconstruction, Holocene, 20, 599608,2010

Garnier, E., Daux, V., Yiou, P., and Garcia de Cortazar, I.: Grapevine harvest dates in Besançon (France) between 1525 and 1847: social outcomes or climatic evidence?, Climatic Change 104, 783801, 2011.

Garnier, M.: Contribution de la phénologie à l'étude des variations climatiques, La Météorologie, 291-300, 1955.

Gladstones, J.: Viticulture and environment, Winetitles, Adelaide, 310 pp., 1992.

Godinot, J.: Manière de cultiver la vigne et de faire le vin en Champagne, et ce qu'on peut imiter dans les autres provinces, pour perfectionner les vins, Reims, 48 pp., 1718.

Guiot, J., Nicault, A., Rathgeber, C., Edouard, J. L., Guibal, F., and Till, C.: Last-millennium summer-temperature variations in western Europe based on proxy data, Holocene, 15, 489-500, 2005.

Guiot, J., Corona, C., and ESCARSEL members: Growing season temperature in Europe and climate forcings for the last 1400 years? PLoS ONE, 5, e9972, doi:10.1371/journal.pone.0009972, 2010.

Guyot, J.: Etude des vignobles de France pour servir à l'enseignement mutuel de la viticulture et de la vinification françaises: Régions du Centre-Nord, du Nord-Est et du NordOuest, 1, Paris, 710 pp., 1868a.

Guyot, J.: Etude des vignobles de France pour servir à l'enseignement mutuel de la viticulture et de la vinification françaises: Régions du Centre-Sud, de l'Est et de l'Ouest, Paris, 739 pp., 1868 b.

Guyot, J.: Etude des vignobles de France pour servir à l'enseignement mutuel de la viticulture et de la vinification françaises: Régions du Sud-Est et du Sud-Ouest, 1, Paris, 623 pp., $1868 \mathrm{c}$.

Holdsworth, J. H.: Memoranda on Tours and Touraine: Including remarks on the climate, with a sketch of the botany and geology of the province, also on the wines and mineral waters of France, Tours, 1842.
Jones, G. V.: Winegrape Phenology, in: Phenology: An Integrative Environmental Science, edited by: Schwartz, M. D., Kluwer Press, 2003.

Jones, G. V., White, M. A., Cooper, O. R., and Storchmann, K.: Climate change and global wine quality, Climatic Change, 73, 319-343, 2005.

Jones, P. D., Briffa, K. R., Osborn, T. J., Lough, J. M., van Ommen, T. D., Vinther, B. M., Luterbacher, J., Wahl, E. R., Zwiers, F. W., Mann, M. E., Schmidt, G. A., Ammann, C. M., Buckley, B. M., Cobb, K. M., Esper, J., Goosse, H., Graham, N., Jansen, E., Kiefer, T., Kull, C., Küttel, M., Mosley-Thompson, E., Overpeck, J. T., Riedwyl, N., Schulz, M., Tudhope, A. W., Villalba, R., Wanner, H., Wolff, E., and Xoplaki, E.: High-resolution palaeoclimatology of the last millennium: a review of current status and future prospects, Holocene, 19, 3-49, 2009.

Keller, M.: Reproductive growth of grapevines in response to nitrogen supply and rootstock, Austr. J. Grape Wine Res., 7, 12-18, 2001.

Klein Tank, A. M. G., Wijngaard, J. B., Können, G. P., Böhm, R., Demarée, G., Gocheva, A., Mileta, M., Pashiardis, S., Hejkrlik, L., Kern-Hansen, C., Heino, R., Bessemoulin, P., MüllerWestermeier, Tzanakou, M., Szalai, S., Pálsdóttir, T., Fitzgerald, D., Rubin, S., Capaldo, M., Maugeri, M., Leitass, A., Bukantis, A., Aberfeld, R., van Engelen, A. F. V., Forland, E., Mietus, M., Coelho, F., Mares, C., Razuvaev, V., Nieplova, E., Cegnar, T., Antonio López, J., Dahlström, B., Moberg, A., Kirchhofer, W., Ceylan, A., Pachaliuk, O., Alexander, V., and Petrovic, P.: Daily dataset of 20th-century surface air temperature and precipitation series for the european climate assessment, Int. J. Climatol., 22, 1441-1453, 2002.

Labbé, T., Gaveau, F., Le Roy Ladurie, E., and Rousseau, D.: Les dates de bans de vendanges à Dijon: établissement critique et révision archivistique d'une série ancienne, Revue Historique, 657, 19-51, doi:10.3917/rhis.111.0019, 2011.

Lavee, S. and May, P.: Dormancy of grapevines buds - facts and speculation, Aust. J. Grape Wine Res., 3, 31-46, 1997.

Le Roy Ladurie, E.: Histoire du climat depuis l'an Mil, Champs Paris, 541 pp., 1967.

Le Roy Ladurie, E.: Canicules, fraîcheurs, vendanges (France 15ème-19ème siècles). C. R. Biologies, 328, 213-218, 2005.

Le Roy Ladurie, E. and Daux, V.: The climate in Burgundy and elsewhere, from the fourteenth to the twentieth century, Interdisc. Sci. Rev., 33, 10-24, 2008.

Le Roy Ladurie, E., Daux, V., and Luterbacher, J.: Le climat de Bourgogne et d'ailleurs. Histoire, Economie et Sociétés, 3, $421-$ 436, 2006.

Legrand, A. P.: Fluctuations météorologiques, vendanges et activité solaire, 2ème Partie, La Météorologie, VI, 173-191, 1978.

Luterbacher, J., Dietrich, D., Xoplaki, E., M., G., and Wanner, H.: European seasonal and annual temperature variability, trends, and extremes since 1500, Science, 303, 1499-1503, 2004.

Manley, G.: Central England Temperatures: monthly means 1659 to 1973, Quart. J. Roy. Meteorol. Soc., 100, 389-405, 1974.

Maugeri, M., Buffoni, L., and Chlistovsky, F.: Daily Milan temperature and pressure series (1763-1998): history of the observations and data and metadata recovery, Climatic Change, 53, 101-117, 2002a.

Maugeri, M., Buffoni, L., Delmonte, B., and Fassina, A.: Daily Milan temperature and pressure series (1763-1998): completing 
and homogenising the data, Climatic Change, 53, 119-142, 2002b.

Meier, N., Rutishauser, T., Pfister, C., Wanner, H., and Luterbacher, J.: Grape harvest dates as a proxy for Swiss April to August temperature reconstructions back to AD 1480, Geophys. Res. Lett., 34, L20705, doi:10.1029/2007GL031381, 2007.

Menzel, A.: A 500 year pheno-climatological view on the 2003 heatwave in Europe assessed by grape harvest dates, Meteorol. Z., 14, 75-77, 2005.

Moberg, A., Jones, P. D., Lister, D., Walther, A., Brunet, M., Jacobeit, J., Alexander, L. V., Della Marta, P. M., Luerbacher, J., Yiou, P., Chen, D., Klein Tank, A. M. G., Saladié, O., Sigró, J., Aguilar, E., Alexandersson, H., Almarza, C., Auer, I., Barriendos, M., Begert, M., Bergström, H., Böhm, R., Butler, C. J., Caesar, J., Drebs, A., Founda, D., Gerstengarbe, F.-W., Micela, G., Maugeri, M., Österle, H., Pandzix, K., Petrakis, M., Srnec, L., Tolasz, R., Tuomenvirta, H., Werner, P. C., Linderholm, H ., Philipp, A., Wanner, H., and Xoplaki, E.: Indices for daily temperature and precipitation extremes in Europe analysed for the period 1901-2000, J. Geophys. Res. Atmos., 111, D22106, doi:10.1029/2006JD007103, 2006.

Odart, A. P.: Ampélographie, ou traité des cépages les plus estimés dans tous les vignobles de quelque renom, Paris, 436 pp., 1845.

Parker, D. and Horton, B.: Uncertainties in Central England temperature 1878-2003 and some improvements to the maximum and minimum series, Int. J. Climatol., 25, 1173-1188, 2005.

Louis-Perrier, M.: Mémoire sur le vin de champagne, edited by: Bonnedame fils, Epernay, p. 11, 1886.

Pfister, C.: Monthly temperature and precipitations in Central Europe 1525-1979: quantifying documentary evidence on weather and its effects, Routledge, 1992.

Pocquet de Livonnière, C.: Traité des fiefs, Paris, 714 pp., 1733.

Rageau, F. and De Laurière, E.: Glossaire du droit français, contenant l'explication des mots difficiles qui se trouvent dans les ordonnances des roys de France, dans les coustumes du royaume, dans les anciens arrests et les anciens titres, Paris, 536 pp., 1704.

Rendu, V.: Ampélographie française comprenant la statistique, la description des meilleurs cépages, l'analyse chimique du sol et les procédés de culture et de vinification des principaux vignobles de la France, 576 pp., 1857.
Rutishauser, T., Luterbacher, J., Jeanneret, F., Pfister, C., and Wanner, H.: A phenology-based reconstruction of interannual changes in past spring seasons, J. Geophys. Res., 112, G04016, doi:10.1029/2006JG000382, 2007.

Salvaing de Boissière, D.: De l'usage des fiefs et autres droits seigneuriaux en Dauphiné Grenoble, 494 pp., 1664.

Saporta, A. D.: La vigne et le vin dans le midi de la France, Paris, 208 pp., 1894.

Schleip, C., Rutishauser, T., Luterbacher, J., and Menzel, A.: Time series modeling and central European temperature impact assessment of phenological records over the last 250 years, J. Geophys. Res., 113, G04026, doi:10.1029/2007JG000646, 2008.

Souriau, A. and Yiou, P.: Grape harvest dates for checking NAO paleoreconstructions, Geophys. Res. Lett., 28, 3895-3898, doi:10.1029/2001GL012870, 2001.

Spahni, P.: The common wine policy and price stabilization, edited by: Avebury, Aldershot, England, 187 pp., 1988.

van Engelen, A. and Nellestijn, J.: Monthly, seasonal and annual means of air temperature in tenths of centigrades in De Bilt, The Netherlands, 1706-1995, 1996.

Van Leeuwen, C., Garnier, C., Agut, C., Baculat, B., Barbeau, G., Besnard, E., Bois, B., Boursiquot, J.-M., Chuine, I., Dessup, T., Dufourcq, T., Garcia-Cortazar I., Marguerite, E., Monamy, C., Koundouras, S., Payan, J.-C., Parker, A., Renouf, V., and Rodriguez-Lovelle, B.: Heat requirements for grapevine varieties is essential information to adapt plant material in a changing climate, VIIème Congrès International des terroirs viticoles, Changins, Switzerland, 2008.

Walker, R. R., Read, P. E., and Blackmore, D. H.: Rootstock and salinity effects on rates of berry maturation, ion accumulation and colour development in shiraz grapes, Austr. J. Grape Wine Res., 6, 227-239, 2000.

Xoplaki, E., Luterbacher, J., Paeth, H., Dietrich, D., Steiner, N., Grosjean, M., and Wanner, H.: European spring and autumn temperature variability and change of extremes over the last half millennium, Geophys. Res. Lett., 32, L15713, doi:10.1029/2005GL023424, 2005.

Yiou, P., García de Cortázar-Atauri, I., Chuine, I., Daux, V., Garnier, E., Viovy, N., van Leeuwen, C., Parker, A. K., and Boursiquot, J.-M.: Continental atmospheric circulation over Europe during the Little Ice Age inferred from grape harvest dates, Clim. Past, 8, 577-588, doi:10.5194/cp-8-577-2012, 2012. 